\title{
Prostaglandin receptors and role of $G$ protein-activated pathways on corpora lutea of pseudopregnant rabbit in vitro
}

\author{
C Boiti, D Zampini, M Zerani ${ }^{1}$, G Guelfi and A Gobbetti ${ }^{1}$ \\ Dipartimento di Patologia, Diagnostica e Clinica veterinaria, Università di Perugia, Via S. Costanzo 4, I-016126 Perugia, Italy \\ ${ }^{1}$ Dipartimento di Biologia Molecolare, Cellulare e Animale, Università di Camerino, Camerino, Italy \\ (Requests for offprints should be addressed to C Boiti; Email: cboiti@unipg.it)
}

\begin{abstract}
Studies were conducted to characterize receptors for prostaglandin (PG) $\mathrm{F}_{2 \alpha}\left(\mathrm{PGF}_{2 \alpha}\right)$ and $\mathrm{PGE}_{2}$, and the signalling pathways regulating total nitric oxide synthase activity and progesterone production in rabbit corpora lutea (CL) of different luteal stages. CL were obtained at days 4, 9 and 13 of pseudopregnancy and cultured in vitro for $2 \mathrm{~h}$ with $\mathrm{PGF}_{2 \alpha}$ or $\mathrm{PGE}_{2}$ and with activators and inhibitors of $\mathrm{G}$ protein $(\mathrm{Gp})$, phospholipase C (PLC), protein kinase $\mathrm{C}(\mathrm{PKC})$, adenylate cyclase $(\mathrm{AC})$ and protein kinase A (PKA).

High affinity $\mathrm{PGF}_{2 \alpha}$ receptor $\left(K_{\mathrm{d}}=1.9 \pm 0.6 \mathrm{nM}\right.$ mean \pm s.E.M. $)$ concentrations increased $(P \leq 0 \cdot 01)$ fourto five-fold from early to mid- and late-luteal phases $(50 \cdot 6 \pm 8 \cdot 5, \quad 188 \cdot 3 \pm 36 \cdot 1$ and $231 \cdot 4 \pm 38 \cdot 8 \mathrm{fmol} / \mathrm{mg}$
\end{abstract}

protein respectively). By contrast, $\mathrm{PGE}_{2}$ receptor $\left(K_{\mathrm{d}}=1.6 \pm 0.5 \mathrm{nM}\right)$ concentrations decreased $(P \leq 0.01)$ from day 4 to day 9 and $13(27 \cdot 5 \pm 7 \cdot 7,12 \cdot 4 \pm 2 \cdot 4$ and $16.5 \pm 3.0 \mathrm{fmol} / \mathrm{mg}$ protein respectively). The Gpdependent AC/PKA pathway was triggered only on day $4 \mathrm{CL}$, mimicking the $\mathrm{PGE}_{2}$ treatment and increasing progesterone production. In both day 9 and day $13 \mathrm{CL}$, the Gp-activated PLC/PKC pathway evoked a luteolytic effect similar to that induced by $\mathrm{PGF}_{2 \alpha}$. The timedependent selective resistance to $\mathrm{PGF}_{2 \alpha}$ and $\mathrm{PGE}_{2}$ by rabbit CL is mediated by factors other than a lack of luteal receptor-ligand interactions.

Journal of Endocrinology (2001) 168, 141-151

\section{Introduction}

There is now considerable direct evidence, derived by both in vivo (Carlson \& Gole 1978, Kehl \& Carlson 1981, Marcinkiewicz et al. 1992) and in vitro studies (O'Grady et al. 1972), supporting the hypothesis that in the rabbit, as in several other animal species, the major luteolytic hormone is prostaglandin $(\mathrm{PG}) \mathrm{F}_{2 \alpha}\left(\mathrm{PGF}_{2 \alpha}\right)$. However, while there is a general agreement upon the luteolytic role of $\mathrm{PGF}_{2 \alpha}$, there is still some controversy about the mechanisms that protect prostaglandin-induced regression of corpora lutea (CL) in both the early- and mid-luteal phase of pseudopregnancy (Marcinkiewicz et al. 1992, Boiti et al. 1998). By contrast, for a long time $\mathrm{PGE}_{2}$ has been recognized as a luteotrophic prostaglandin, as it may protect the CL from many of the actions induced by $\mathrm{PGF}_{2 \alpha}$ (Zelinsky-Wooten \& Stouffer 1990, Ford \& Christenson 1991).

It is also widely accepted that the effects induced by PGs reflect the interactions on target cells with specific surface receptors, and probably with different receptor subtypes, which influence second messenger systems via $G$ protein (Gp) activation. Therefore, the increasing responsiveness of CL to $\mathrm{PGF}_{2 \alpha}$, or its analogues, during subsequent luteal developmental stages (Boiti et al. 1998), from total to partial refractoriness and complete luteolysis, may be due to changes in the number of receptors for $\mathrm{PGF}_{2 \alpha}$ and/or $\mathrm{PGE}_{2}$.

Recently we demonstrated, by in vitro studies on CL of pseudopregnant rabbits, that $\mathrm{PGF}_{2 \alpha}$ and $\mathrm{PGE}_{2}$ affect progesterone release differently, depending on the luteal stage, by regulating the activity of nitric oxide synthase (NOS), the enzyme which controls nitric oxide (NO) production (Boiti et al. 2000). On day $4 \mathrm{CL}, \mathrm{PGE}_{2}$ was found to depress NOS activity and increase progesterone production, but was totally ineffective on day 9 CL. Prostaglandin $\mathrm{F}_{2 \alpha}$ up-regulated NOS activity and induced functional luteolysis in day $9 \mathrm{CL}$, but had no effect on young CL collected at the early luteal phase.

Several studies have documented a good correlation between in vitro binding specificity and concentrations of prostaglandin receptors for $\mathrm{PGF}_{2 \alpha}$ in membranes prepared from CL of several species and its luteolytic activity in vivo (Rao 1974, Wright et al. 1980). Additional reports have shown that plasma membrane receptors for $\mathrm{PGE}_{2}$ in luteal tissue and luteal cells are also related to the functional status of CL during the oestrous cycle and pregnancy (Wiepz et al. 1992, Feng \& Almond 1996). The presence of $\mathrm{PGF}_{2 \alpha}$ and $\mathrm{PGE}_{2}$ binding sites in both large and small luteal cells has been verified in cow (Alila et al. 1987, 
Chegini et al. 1991), sheep (Balapure et al. 1989) and monkey (Brannian \& Stouffer 1991) resulting in some discrepancies probably reflecting species differences (Niswender et al. 1985). However, the specific binding sites for either $\mathrm{PGF}_{2 \alpha}$ or $\mathrm{PGE}_{2}$ have not been investigated in the rabbit.

The present work was undertaken to examine the affinity and concentration of receptors for $\mathrm{PGF}_{2 \alpha}$ and $\mathrm{PGE}_{2}$ on $\mathrm{CL}$ of rabbits in the early-, mid- and late-luteal phase at days 4, 9 and 13 of pseudopregnancy by radioligand binding. These stages of pseudopregnancy were selected because the corresponding CL showed different age-related responsiveness to $\mathrm{PGF}_{2 \alpha}$ in vivo (Carlson \& Gole 1978, Marcinkiewicz et al. 1992, Boiti et al. 1998). Moreover, to better elucidate the differential age-related effects of PGs and the sites of their functional actions on progesterone release and total NOS activity, the signal transduction pathway was activated in vitro in a stepwise fashion at the level of the receptor $(\mathrm{Gp})$, phospholipase C (PLC) and protein kinase $\mathrm{C}$ (PKC), adenylate cyclase (AC) and protein kinase A (PKA). Additionally, the regulatory role of Gps in both luteolytic and luteotrophic actions was studied by adding a number of inhibitors for PLC, PKC, AC and PKA together with a NOS inhibitor (L-NAME).

\section{Materials and Methods}

\section{Materials}

Medium 199 was obtained from Gibco (Grand Island, NY, USA). Hepes, $\mathrm{NaHCO}_{3}, \mathrm{BSA}, \mathrm{PGF}_{2 \alpha}$ and $\mathrm{PGE}_{2}$ were purchased from Sigma (Sigma Chemical Co., St Louis, MO, USA). $\left[1,2,6,7-{ }^{3} \mathrm{H}\right]$ Progesterone was purchased from Amersham Int. (Buckinghamshire, UK), while non-radioactive progesterone and progesterone antiserum came from Sigma. $\left.{ }^{3} \mathrm{H}\right] \mathrm{PGF}_{2 \alpha}(5,6,8,9,11,12$, $\left.14,15-{ }^{3} \mathrm{H}(\mathrm{N})-\mathrm{PGF}_{2 \alpha}, 218 \mathrm{Ci} / \mathrm{mmol}, \mathrm{NET} 433\right)$ and $\left[{ }^{3} \mathrm{H}\right] \mathrm{PGE}_{2} \quad\left(5,6,8,11,12,14,15-{ }^{3} \mathrm{H}(\mathrm{N})-\mathrm{PGE}_{2}, \quad 200 \mathrm{Ci} /\right.$ mmol, NET 428) were purchased from New England Nuclear (Boston, MA, USA). Tissue culture plates with 24 flat bottom wells were obtained from Becton Dickinson \& Co. (Clifton, NJ, USA). Bio-Rad Protein Assay kit was obtained from Bio-Rad Lab (Hercules, CA, USA). The following activators were purchased from Calbiochem Corp. (San Diego, CA, USA): Gp, guanosine 5'-O-(3thiotriphosphate) (GTP $\gamma-\mathrm{S})$; PLC, imipramine; PKC, phorbol-12-myristate-13-acetate (PMA); AC, forskolin, 7-deacetyl-7-[O-(N-methylpiperaziono)- $\gamma$-butyryl] (L85 8051); PKA, adenosine $3^{\prime}, 5^{\prime}$-cyclic monophosphate, 8-bromo (8-bromo-cAMP). The following inhibitors for Gp, guanosine 5'-O-(2-thiodiphosphate), (GDP $\beta$-S); PLC, ET-18-OCH ${ }_{3}$; PKA, compound H89 were also purchased from Calbiochem, while those for PKC, staurosporine, AC, 2-O-methyladenosine, NOS, L-NAME came from Sigma. $\left[2,3-{ }^{3} \mathrm{H}\right] \mathrm{L}-$ Arginine, having a specific activity of $30-40$
$\mathrm{Ci} / \mathrm{mmol}$, was purchased from Sigma. Scintillation fluid, Ultima Gold, was obtained from Packard (Groningen, The Netherlands). Multiscreen Assay System and FB Microplate Glass Fiber Type B Filter (MAFB NOB 10) were purchased from Millipore (Molsheim, France). Tris salt, and all reagent ACS grade were also obtained from Sigma. The kit for the assay of NOS (NOS detectTM) was purchased from Alexis (Alexis Corp., Läufelfingen, Switzerland)

\section{Animals, hormonal regimen and tissue collection}

All experiments utilized CL obtained from unmated New Zealand White female rabbits (HY/CR, Charles River Italia, Calco, LC, Italy), age 5 months, weighing 3.5$3.8 \mathrm{~kg}$. The animals were kept at the University of Perugia Central Animal Facility under controlled condition of light (14 h light : $10 \mathrm{~h}$ darkness) and temperature $\left(18^{\circ} \mathrm{C}\right)$, and were given water and commercial pellets and allowed to feed ad libitum.

The rabbits received an i.m. injection of 20 IU pregnant mare serum gonadotrophin (Folligon, Intervet Italia, Milan, Italy) followed 3 days later by an i.m. injection of $0 \cdot 8 \mu \mathrm{g}$ gonadotrophin-releasing hormone $(\mathrm{GnRH})$ analogue (Receptal, Roussel-Hoechst, Munich, Germany) to induce pseudopregnancy. The day of GnRH injection was designated day 0 . Rabbits were killed on days 4, 9 and 13 of pseudopregnancy by cervical dislocation. CL were promptly removed from the ovary and, immediately upon collection, were washed with saline and then transferred onto filter paper to dissect away the non-luteal tissue with fine forceps under stereoscopic magnification. For each luteal stage, CL from different rabbits were combined together onto ice-cold medium 199 containing 1\% BSA and immediately processed for the in vitro study. Additional CL from different rabbits were randomly pooled together on the basis of the day of pseudopregnancy, weighed and stored at $-70{ }^{\circ} \mathrm{C}$ until assayed for prostaglandin receptors.

\section{In vitro incubations}

CL from each luteal stage were randomly distributed (one $\mathrm{CL} /$ well) into incubation wells containing $1 \mathrm{ml}$ culture medium 199 with Earle's Balanced Salt Solution containing $2.2 \mathrm{mg} / \mathrm{ml}$ sodium bicarbonate, $2.3 \mathrm{mg}$ Hepes and $1 \%$ BSA, referred to here as M199. For each day of pseudopregnancy, the incubation set of wells was divided into 26 experimental groups. Before treatment, the CL were quartered inside each well using fine forceps. Treatments, performed in four replicate samples, are listed as follows: (1) control (medium alone), (2) $\mathrm{PGE}_{2}(3 \mu \mathrm{M})$, (3) $\mathrm{PGE}_{2}$ plus $\mathrm{Gp}$ inhibitor $(\mathrm{Gpi}, 2 \mu \mathrm{M})$, (4) $\mathrm{PGF}_{2 \alpha}(3 \mu \mathrm{M})$, (5) $\mathrm{PGF}_{2 \alpha}$ plus Gpi, and (6) Gpi alone. Additional treatments were (7) Gp activator (Gpa, $0 \cdot 2 \mu \mathrm{M})$, (8) Gpa plus AC inhibitor (ACi $1 \mu \mathrm{M})$, (9) Gpa plus PKA inhibitor (PKAi, $2 \mu \mathrm{M})$, (10) Gpa plus PLC inhibitor (PLCi, $2 \mu \mathrm{M}$ ), 


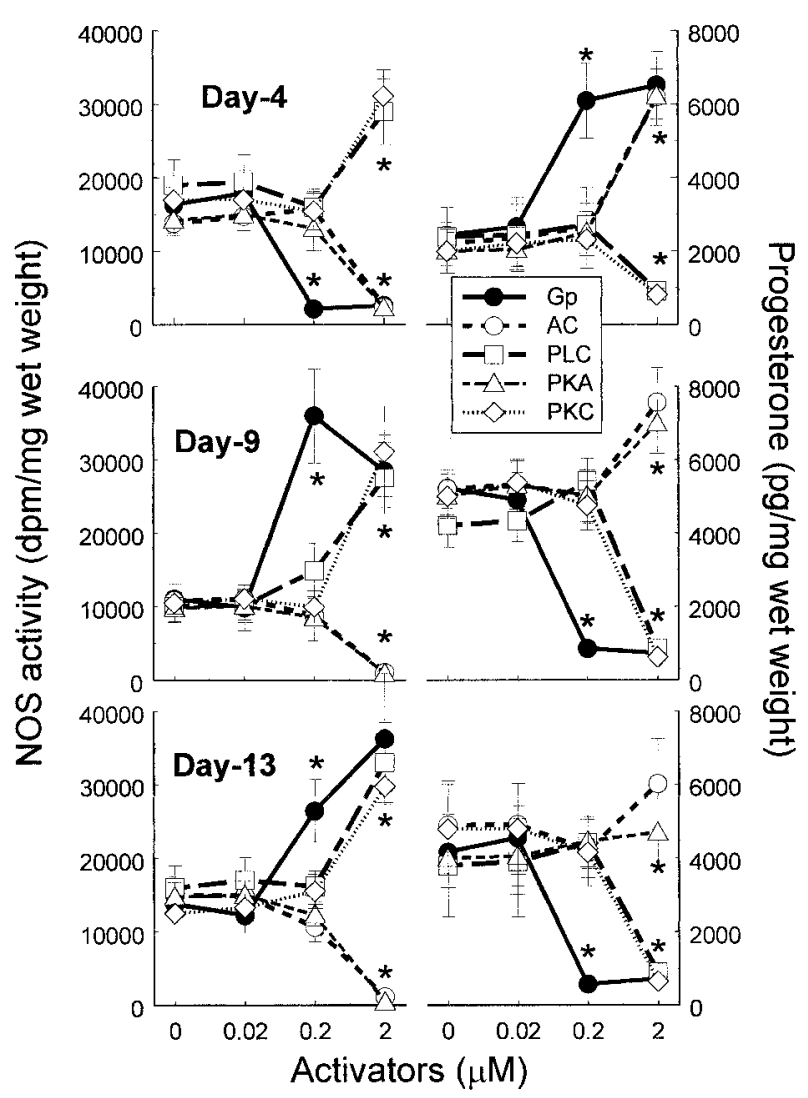

Figure 1 In vitro effects of increasing concentrations of activators for Gp (GTP $\gamma$-S), AC (forskolin), PLC (imipramine), PKA (8-bromoCAMP) and PKC (PMA) on total NOS activity (left-hand side) and progesterone release (right-hand side) by rabbit CL collected during early-, mid- and late-luteal phases of pseudopregnancy, on days 4,9 and 13 respectively, and incubated for $2 \mathrm{~h}$. Values are means \pm S.D.s of three determinations. Within each panel, the asterisk indicates significantly different values $(P \leq 0 \cdot 01$ Duncan's multiple range test with respect to other doses of the same compound).

(11) Gpa plus PKC inhibitor (PKCi, $2 \mu \mathrm{M})$, (12) Gpa plus NOS inhibitor (NOSi, $1 \mu \mathrm{M}$ ), (13) ACi alone, and (14) PLCi alone. Other treatments were (15) AC activator (ACa, $2 \mu \mathrm{M})$, (16) ACa plus PKA inhibitor $(2 \mu \mathrm{M})$, (17) ACa plus NOSi, (18) PKA activator (PKAa, $2 \mu \mathrm{M}$ ), (19) PKAi, (20) PKAa plus NOSi, (21) PLC activator (PLCa, $2 \mu \mathrm{M})$, (22) PLCa plus PKCi, (23) PLCa plus NOSi, (24) $\mathrm{PKC}$ activator (PKCa, $2 \mu \mathrm{M})$, (25) PKCa plus NOSi, and (26) $\mathrm{PKCi}$ alone. The culture plates were incubated at $37^{\circ} \mathrm{C}$ in air with $5 \% \mathrm{CO}_{2}$ as reported elsewhere (Gobbetti et al. 1999, Boiti et al. 2000). CL and media were collected $2 \mathrm{~h}$ after the addition of treatments and stored immediately at $-20{ }^{\circ} \mathrm{C}$ for later determination of NOS activity and progesterone levels. Minimum doses of activating substances (Fig. 1) and inhibitors used in the present in vitro study were defined by preliminary experiments.
NOS activity determination

NOS activity was determined in each CL by monitoring the conversion of $\left[{ }^{3} \mathrm{H}\right] \mathrm{L}$-arginine into $\left[{ }^{3} \mathrm{H}\right] \mathrm{L}$-citrulline, with a commercial NOS assay kit, according to the experimental protocol as previously described (Boiti et al. 2000).

\section{Progesterone assay}

Progesterone concentrations in the incubation medium samples were determined following the RIA previously reported (Gobbetti et al. 1992). The assay sensitivities were $10 \mathrm{pg} / \mathrm{ml}$, with a working range of the RIA in culture medium of $1-5 \mathrm{pg} / \mathrm{ml}$. Intra-assay and interassay coefficients of variations were $6 \%$ and $11 \%$ respectively.

\section{Radio-receptor assays}

The $\mathrm{PGE}_{2}$ and $\mathrm{PGF}_{2 \alpha}$ receptor assays were similar to those reported by Wiepz et al. (1992). Briefly, for each day of pseudopregnancy, $50 \mathrm{mg}$ luteal tissue were homogenized in $5 \mathrm{ml}$ ice-cold homogenization buffer (HB: $10 \mathrm{mM}$ Tris- $\mathrm{HCl} \mathrm{pH} 7 \cdot 0$, containing $250 \mathrm{mM}$ sucrose, $1 \mathrm{mM}$ $\mathrm{CaCl}_{2}, 1 \mathrm{mM} \mathrm{MgCl}_{2}$ and $0.02 \% \mathrm{NaN}_{3}$ ) with Polytron PT 1200 for five strokes $(5 \mathrm{~s} \times 2500$ r.p.m.) interspersed with $20 \mathrm{~s}$ cooling periods. The homogenate was centrifuged at $100 \mathrm{~g}$ at $4{ }^{\circ} \mathrm{C}$ for $15 \mathrm{~min}$. Pellet was discarded and supernatant was centrifuged at $30000 \mathrm{~g}$ at $4{ }^{\circ} \mathrm{C}$ for $30 \mathrm{~min}$. The resulting pellet was resuspended in $2 \mathrm{ml} \mathrm{HB}$ with two strokes of Polytron on ice, and its protein concentration was determined according to the procedure described by Rao et al. (1984), using a commercial kit. The concentration and affinity of $\mathrm{PGF}_{2 \alpha}$ and $\mathrm{PGE}_{2}$ for specific luteal membrane receptors were assayed by a saturation analysis, using the Multiscreen Assay System device for multiple filtration of unbound radioligands. One hundred micrograms of luteal membrane suspension in $75 \mu \mathrm{l}$ assay buffer (AB: $10 \mathrm{mM}$ Tris- $\mathrm{HCl} \mathrm{pH}$ 6.0, containing $10 \mathrm{mM} \mathrm{CaCl}_{2}, 10 \mathrm{mM} \mathrm{MgCl}, 1 \cdot 0 \% \mathrm{BSA}$ and $0.02 \%$ $\mathrm{NaN}_{3}$ ) were dispensed in triplicate into separate wells of a microtitre glass fibre filter plate. Twenty-five microlitres of five serial dilutions of $\left[{ }^{3} \mathrm{H}\right] \mathrm{PGF}_{2 \alpha}$ (2 to $\left.0 \cdot 125 \mathrm{nM}\right)$ in $\mathrm{AB}$ were then added to each well. The same volume of $A B$ alone or $\mathrm{PGF}_{2 \alpha}(10 \mu \mathrm{M})$ was dispensed to total bound (TB) and non-specific binding series of wells (NSB) respectively. The same protocol scheme was repeated to assay $\mathrm{PGE}_{2}$ receptor, using $\left[{ }^{3} \mathrm{H}\right] \mathrm{PGE}_{2}$ and $\mathrm{PGE}_{2}$ instead of $\mathrm{PGF}_{2 \alpha}$ at the same molar concentrations. The $\mathrm{PGF}_{2 \alpha}$ plates were incubated for $2 \mathrm{~h}$ at $22^{\circ} \mathrm{C}$, while the $\mathrm{PGE}_{2}$ plates were kept overnight at $4{ }^{\circ} \mathrm{C}$. At the end of the incubation period each well was washed three times with $300 \mu \mathrm{l}$ ice-cold saline. The well filters at the bottom of the microplate were carefully blotted on paper, air-dried and cut into separate microvials using the multiple punch assembly of the Multiscreen device. Three millilitres 
scintillation fluid were added into each vial and radioactivity was counted on TRICARB 2100 TR liquid scintillation analyser (Packard Camberra).

Specific binding was calculated as the difference between total and non-specific $\left[{ }^{3} \mathrm{H}\right] \mathrm{PGF}_{2 \alpha}$ or $\left[{ }^{3} \mathrm{H}\right] \mathrm{PGE}_{2}$ binding, normalized to protein content.

\section{Data analysis and statistics}

Data for dose-response studies and for effects of treatment on release of progesterone and on basal NOS activity were submitted to ANOVA and Kruskal-Wallis test (Sokal \& Rohlf 1981) followed by Duncan's multiple range test for multiple comparison to the control (Duncan 1955). For each day of pseudopregnancy, the individual contrast between treatment groups was made with an unpaired two-tailed Student's $t$-test.

Binding curves were analysed with an iterative, nonlinear curve-fitting computer program (PRISM GraphPad Software, San Diego, CA, USA). Data for receptor concentrations $\left(B_{\max }\right)$ and apparent dissociation constant $\left(K_{\mathrm{d}}\right)$ of binding sites are expressed as mean \pm s.E.M. Data from $\left[{ }^{3} \mathrm{H}\right] \mathrm{PGF}_{2 \alpha}$ and $\left[{ }^{3} \mathrm{H}\right] \mathrm{PGE}_{2}$ binding assays were analysed by one-way ANOVA with Dunnett's post test.

\section{Results}

The total NOS activity in rabbit CL cultured with medium alone after $2 \mathrm{~h}$ in vitro incubation was lower $(P \leq 0 \cdot 01)$ on day $9 \mathrm{CL}(10886 \pm 1170$ d.p.m./mg wet tissue) than on day 4 and day 13 CL (15 $409 \pm 1598$ and $14639 \pm 1445$ respectively). By contrast, at the end of the incubation period, the corresponding basal progesterone production was higher $(P \leq 0 \cdot 01)$ on day 9 CL $(4970 \pm 245 \mathrm{pg} / \mathrm{mg}$ wet tissue) than on CL of day 4 and 13 (2781 \pm 284 and $3917 \pm 569$ respectively).

In all CL preparations, independently of their age, the co-treatment with any of the activators here tested and L-NAME resulted in an inhibition $(P \leq 0 \cdot 01)$ of NOS activity and in a concomitant increase $(P \leq 0.01)$ of progesterone release (Figs 4 and 5).

The dose-dependent effects of increasing concentrations of activators for $\mathrm{G}$ proteins, AC and PLC added to the incubation medium on both NOS activity and progesterone secretion in CL of different luteal stages after $2 \mathrm{~h}$ in vitro incubations are shown in Fig. 1. Independently of the activators here employed, whenever a response was observed the progesterone release was always inversely related $(P \leq 0 \cdot 01)$ to the NOS activity.

Effects of prostaglandins on NOS activity and progesterone production by in vitro cultured $C L$

On day $4 \mathrm{CL}, \mathrm{PGE}_{2}$ addition to the medium, at a concentration of $3 \mu \mathrm{M}$, decreased $(P \leq 0 \cdot 01)$ NOS activity

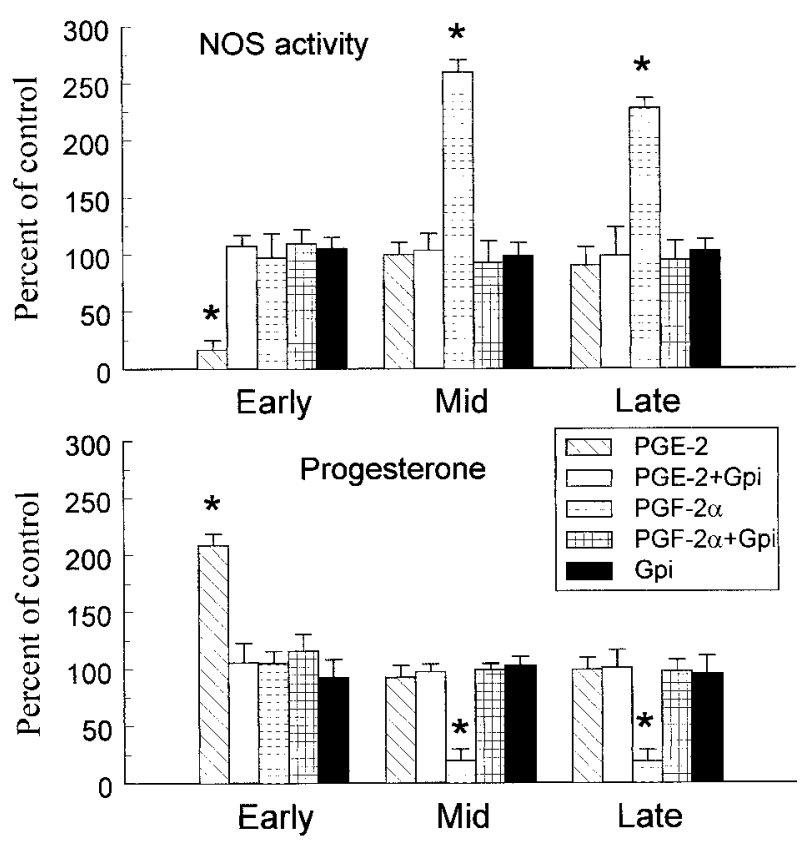

Luteal stages of pseudopregnancy

Figure 2 In vitro effects of $\mathrm{PGE}_{2}$ and $\mathrm{PGF}_{2 \alpha}$ both alone and co-incubated with guanosine $5^{\prime}$-O-(2-thiodiphosphate), an inhibitor for $\mathrm{G}$ protein (Gpi), and Gpi alone on NOS total activity (upper panel) and progesterone release (lower panel) of rabbit $\mathrm{CL}$ collected during early-, mid- and late-luteal stages of pseudopregnancy on days 4, 9 and 13 respectively, after 2-h incubation. Results are the means \pm S.D.s of four replicate values and are expressed as a percentage of the control values incubated with medium alone. Means \pm S.D.s of NOS activities in the CL incubated with medium alone were $15409 \pm 1598,10886 \pm 1170$ and $14639 \pm 1445$ d.p.m./mg wet tissue at days 4,9 and 13 respectively, while those of progesterone were $2 \cdot 8 \pm 0 \cdot 3,4 \cdot 9 \pm 0 \cdot 3$ and $3.9 \pm 0.6 \mathrm{ng} / \mathrm{mg}$ respectively. Within each panel, an asterisk above the bars of each luteal stage of pseudopregnancy indicates significantly different values ( $P \leq 0 \cdot 01$ Duncan's multiple range test).

to $16 \%$ of control and caused a twofold increase $(P \leq 0 \cdot 01)$ in progesterone production over that of control (Fig. 2). The same treatment, however, was ineffective in both mid- and late-phase CL. By contrast, at the end of the incubation period, $\mathrm{PGF}_{2 \alpha}$ stimulated a two- to threefold increase $(P \leq 0 \cdot 01)$ of NOS baseline activity in rabbit CL tissue preparations of both days 9 and 13 of pseudopregnancy respectively and reduced $(P \leq 0 \cdot 01)$ progesterone release to $19-20 \%$ of the control (Fig. 2). However, in CL preparation of day 4 , the addition of $\mathrm{PGF}_{2 \alpha}$ did not affect progesterone production and NOS activity, which remained unchanged after the same time interval. The specific and age-dependent selective activation of the prostaglandin signal transduction pathways was blocked by the addition of a Gp inhibitor. In fact, independently of the luteal stages, the co-treatments of CL with Gpi and either $\mathrm{PGE}_{2}$ or $\mathrm{PGF}_{2 \alpha}$ failed to induce any response on 


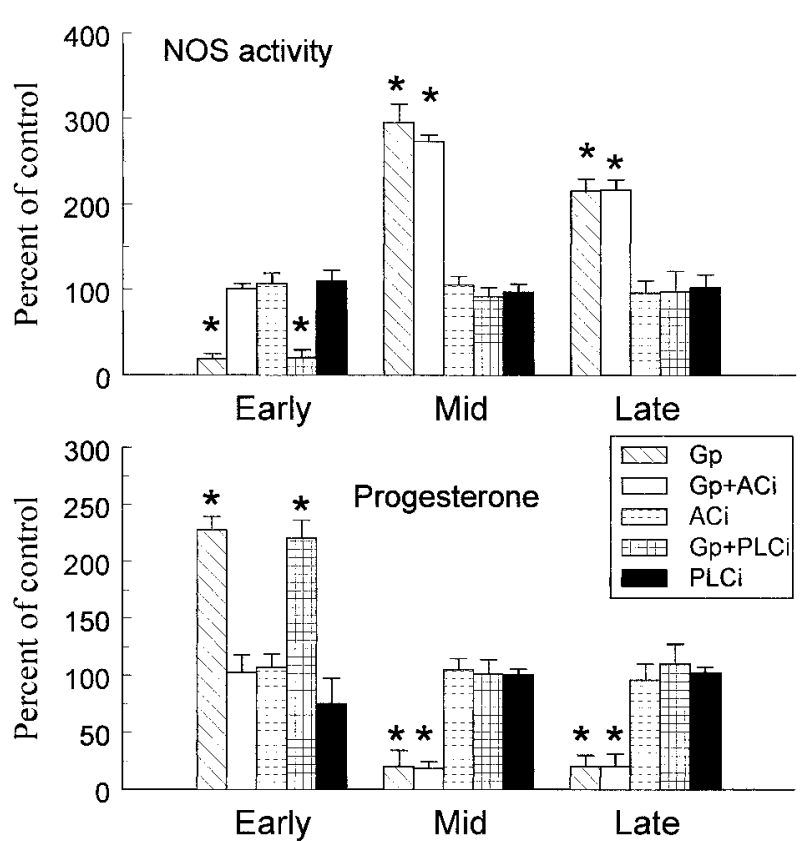

Luteal stages of pseudopregnancy

Figure 3 In vitro G protein signal transduction effects on NOS total activity (upper panel) and progesterone release (lower panel) of rabbit CL collected during early-, mid- and late-luteal stages of pseudopregnancy on days 4, 9 and 13 respectively, after 2-h incubation. Gp refers to guanosine 5'-O-(3-thiotriphosphate), a G protein activator, while $\mathrm{ACi}$ and $\mathrm{PLCi}$ refer to inhibitors of adenylate cyclase (2-O-methyladenosine) and phospholipase C $\left(\mathrm{ET}-18-\mathrm{OCH}_{3}\right)$ respectively. Results are the means \pm S.D.s of four replicate values and are expressed as a percentage of the control values incubated with medium alone. Means \pm S.D.s of NOS activities in the CL incubated with medium alone were $15409 \pm$ $1598,10886 \pm 1170$ and $14639 \pm 1445$ d.p.m./mg wet tissue at days 4,9 and 13 respectively, while those of progesterone were $2 \cdot 8 \pm 0 \cdot 3,4 \cdot 9 \pm 0 \cdot 3$ and $3 \cdot 9 \pm 0.6 \mathrm{ng} / \mathrm{mg}$ wet tissue respectively. Within each panel, an asterisk above the bars of each luteal stage of pseudopregnancy indicates significantly different values $(P \leq 0.01$ Duncan's multiple range test).

either total NOS activity or progesterone production, and had values close to those of the corresponding untreated CL or CL treated with Gp inhibitor alone (Fig. 2).

\section{Effects of in vitro activation of G protein on NOS activity and progesterone release}

The addition of $0 \cdot 2 \mu \mathrm{M}$ GTP $\gamma-\mathrm{S}$, an activator of the G protein family, induced a fivefold decrease $(P \leq 0 \cdot 01)$ of basal NOS activity in day $4 \mathrm{CL}$, but a two- to threefold increase $(P \leq 0.01)$ in CL of both day 9 and 13 (Fig. 3). In the same CL preparations, after $2 \mathrm{~h}$ in vitro incubation, progesterone output exhibited an opposite trend (Fig. 3). In fact, in day $4 \mathrm{CL}$, steroidogenesis was enhanced $(P \leq 0 \cdot 01) 228 \%$ over that of control as in CL treated with $\mathrm{PGE}_{2}$. Conversely, in CL of both days 9 and 13, activation of the Gp system caused a marked decrease $(P \leq 0 \cdot 01)$ in progesterone production to values similar to those observed following in vitro $\mathrm{PGF}_{2 \alpha}$ treatment.

The co-addition into the culture medium of specific inhibitors for the AC system blocked the Gpa-induced effects on both NOS activity and progesterone release of day $4 \mathrm{CL}$, while inhibitors of the PLC system did not affect Gpa-mediated effects (Fig. 3). Conversely, in CL of both days 9 and 13, PLC inhibitor counteracted the Gpa-induced effects, while AC inhibitor was ineffective (Fig. 3). Similar luteal stage dependent results were obtained by co-treatments of Gpa with PKA and PKC inhibitors (data not shown). Incubations of CL with AC and PLC inhibitors had no effects (Fig. 3).

Effects of in vitro activation of AC/PKA system on NOS activity and progesterone release

The stimulation of the AC/PKA cascade by the addition of either forskolin or 8-bromo-cAMP down-regulated NOS activity in CL of days 4, 9 and 13 (Fig. 4). In day 4 CL, the effects induced by in vitro activation of the AC/PKA system overlapped that evoked by $\mathrm{PGE}_{2}$. By contrast, in mid- and late-luteal phase CL, the inhibition of NOS activity was much higher $(P \leq 0 \cdot 01)$ than in day $4 \mathrm{CL}$ and similar to that obtained in CL co-treated with the NOS inhibitor, L-NAME. On day 4 CL, the effects of both AC and PKA activators mimicked $\mathrm{PGE}_{2}$ treatment by increasing basal progesterone secretion $223 \%$ over that of control, while on day $9 \mathrm{CL}$ the luteotrophic effect was less effective as progesterone production rose $(P \leq 0 \cdot 01)$ only $50 \%$ over that of controls (Fig. 4). Conversely, in day $13 \mathrm{CL}$ progesterone release remained unaffected by treatments with both AC and PKA activators. In CL of all ages, the co-treatment with PKA inhibitor abolished the luteotrophic effect induced by the AC activator by restoring NOS activity and progesterone release to their respective basal control values (Fig. 4). Treatment with PKA inhibitor alone had no effect on both NOS activity and progesterone release (Fig. 4).

Effects of in vitro activation of PLC/PKC system on NOS activity and progesterone release

The in vitro treatments with either the PLC or the PKC system activator greatly decreased $(P \leq 0 \cdot 01)$ progesterone production by CL preparations independently of their age (Fig. 5). The effects on the NOS activity induced by these treatments were opposed and caused a two- to threefold increase $(P \leq 0 \cdot 01)$ of basal NOS activity over that of controls (Fig. 5). The co-addition of the PKC inhibitor to CL treated with PLC activator abolished the luteolytic effect and the up-regulation of NOS activity. Similar results were obtained by treatment with PKC inhibitor 


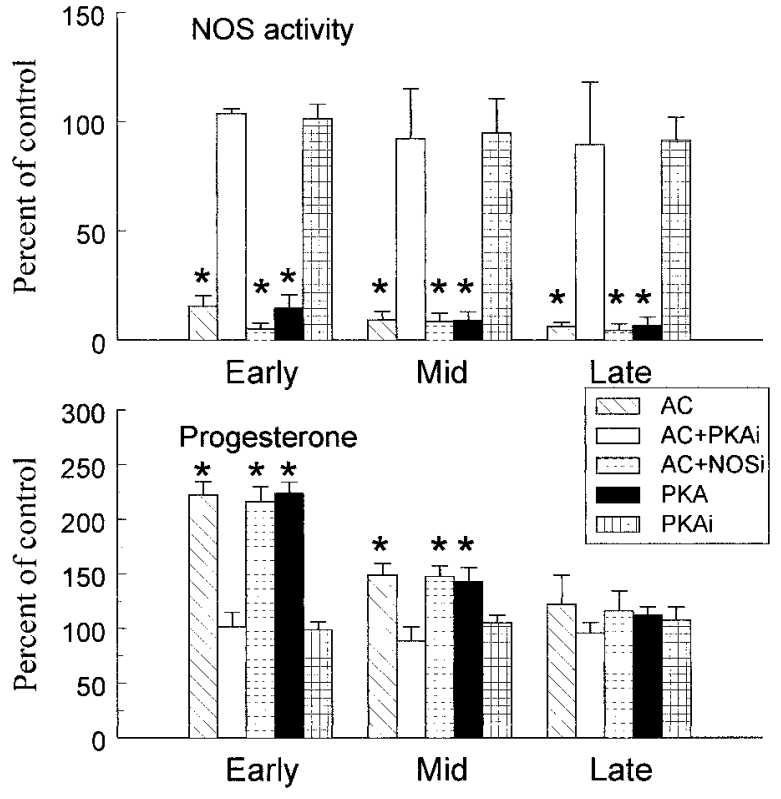

Luteal stages of pseudopregnancy

Figure 4 In vitro activation of the AC/PKA system on NOS total activity (upper panel) and progesterone release (lower panel) of rabbit CL collected during early-, mid- and late-luteal stages of pseudopregnancy on days 4, 9 and 13 respectively after 2-h incubation. AC and PKA refer to activators of adenylate cyclase (forskolin) and protein kinase A (8-bromo-cAMP), while PKAi and NOSi refer to inhibitors of PKA (compound H89) and NOS (L-NAME) respectively. Results are the means \pm S.D.s of four replicate values and are expressed as a percentage of the control values incubated with medium alone. Means \pm S.D.s of NOS activities in the CL incubated with medium alone were $15409 \pm$ $1598,10886 \pm 1170$ and $14639 \pm 1445$ d.p.m./mg wet tissue at days 4,9 and 13 respectively, while those of progesterone were $2 \cdot 8 \pm 0 \cdot 3,4 \cdot 9 \pm 0 \cdot 3$ and $3 \cdot 9 \pm 0 \cdot 6 \mathrm{ng} / \mathrm{mg}$ wet tissue respectively. Within each panel, an asterisk above the bars of each luteal stage of pseudopregnancy indicates significantly different values $(P \leq 0 \cdot 01$ Duncan's multiple range test).

alone. In fact, both progesterone release and total NOS activity remained unchanged, having values close to those found in control CL of the same ages (Fig. 5).

\section{Binding affinities and concentrations of $P G F_{2 a}$ and $P G E_{2}$} receptors

Saturation curves and Scatchard plot transformations derived by binding isotherms for each prostaglandin in the different luteal stages are shown in Fig. 6. Independently of the luteal stages, the concentrations of receptor sites for $\mathrm{PGF}_{2 \alpha}$ were greater than the concentrations for $\mathrm{PGE}_{2}$ receptors, but increased markedly over those for $\mathrm{PGE}_{2}$ from twofold on day 4 CL to 15 -fold on CL of both midand late-luteal stages (Fig. 7). The concentration of receptors for $\mathrm{PGF}_{2 \alpha}$ increased $(P \leq 0 \cdot 01)$ four- to fivefold from early to mid- and late-luteal phase, being highest on day

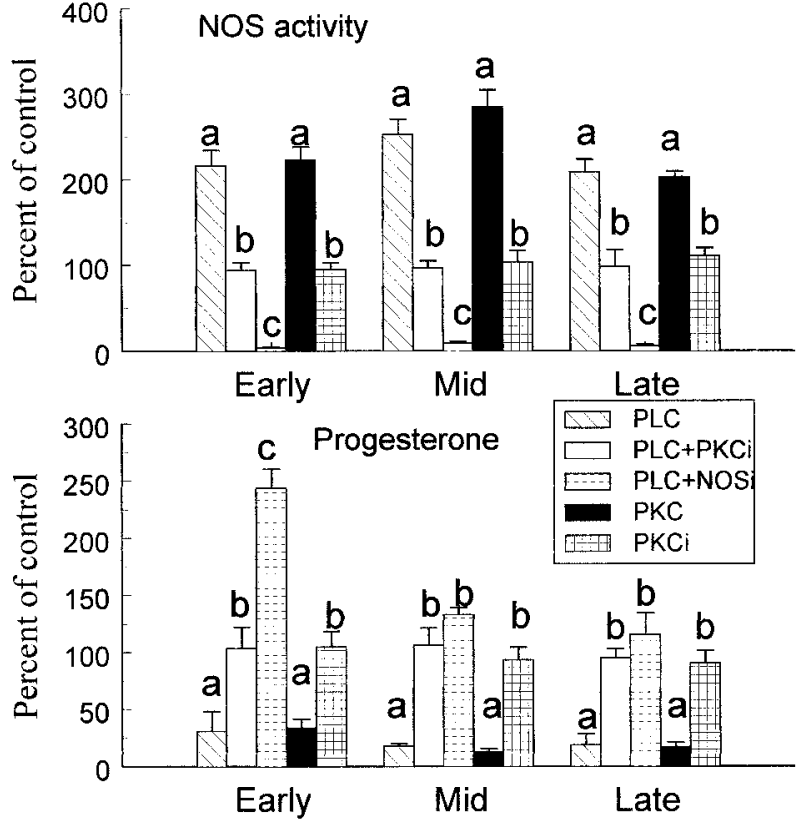

Luteal stages of pseudopregnancy

Figure 5 In vitro activation of the PLC/PKC system on NOS total activity (upper panel) and progesterone release (lower panel) of rabbit $C L$ collected during early-, mid- and late-luteal stages of pseudopregnancy on days 4, 9 and 13 respectively after 2-h incubation. PLC and PKC refer to activators of phospholipase C (imipramine) and protein kinase $\mathrm{C}$ (PMA), while PKCi and NOSi refer to inhibitors of PKC (staurosporine) and NOS (L-NAME) respectively. Results are the means \pm S.D.s of four replicate values and are expressed as a percentage of the control values incubated with medium alone. Means \pm S.D.S of NOS activities in the $\mathrm{CL}$ incubated with medium alone were $15409 \pm 1598,10886 \pm$ 1170 and $14639 \pm 1445$ d.p.m./mg wet tissue at days 4,9 and 13 respectively, while those of progesterone were $2 \cdot 8 \pm 0 \cdot 3$, $4.9 \pm 0.3$ and $3.9 \pm 0.6 \mathrm{ng} / \mathrm{mg}$ wet tissue respectively. Within each panel, different letters above the bars of each luteal stage of pseudopregnancy indicate significantly different values $(P \leq 0 \cdot 01$ Duncan's multiple range test).

$13 \mathrm{CL}$. By contrast, on day $4 \mathrm{CL}$ the concentration of receptors for $\mathrm{PGE}_{2}$ was highest $(P \leq 0 \cdot 01)$ compared with lower values found in older CL. In CL of mid-luteal phase, the dissociation constants $\left(K_{\mathrm{d}}\right)$ for the receptors for $\mathrm{PGE}_{2}$ and $\mathrm{PGF}_{2 \alpha}$ were $1.6 \pm 0.5$ and $1.9 \pm 06 \mathrm{nM}$ respectively. Similar values were obtained also in CL of early and late-luteal phases. For each prostaglandin, slope factors for the competition curves were not statistically different from 1 , suggesting a ligand receptor interaction that could be explained by a one-site binding model.

\section{Discussion}

Although the involvement of receptors for both $\mathrm{PGF}_{2 \alpha}$ and $\mathrm{PGE}_{2}$ has been postulated in $\mathrm{CL}$ of pseudopregnant 

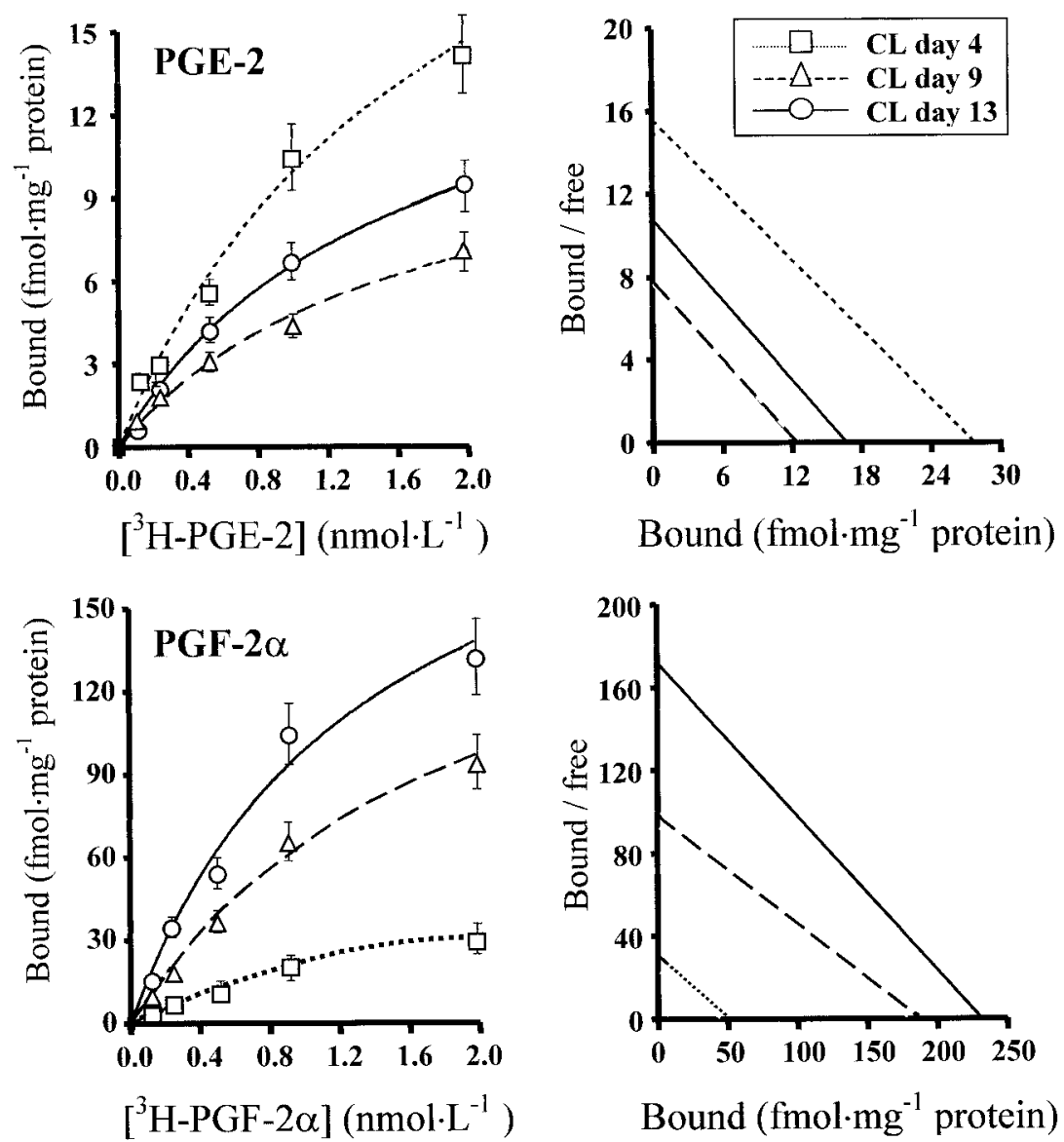

Figure 6 Representative saturation curves (left side) and Scatchard plots (right side) from one of three independent experiments of $\left[{ }^{3} \mathrm{H}\right] \mathrm{PGE}_{2}$ (upper panels) and $\left[{ }^{3} \mathrm{H}\right] \mathrm{PGF}_{2 \alpha}$ (lower panels) binding to luteal membrane fraction homogenates prepared from pooled rabbit $\mathrm{CL}$ collected at the early-, mid- and late-luteal phase on days 4, 9 and 13 of pseudopregnancy.

Values are the means \pm S.E.M.S.

rabbits on the basis of their luteolytic and luteotrophic actions (Boiti et al. 2000), this work is the first direct evidence for their existence in this species. Independently of CL age, luteal cells have now been clearly shown to display luteal membrane binding sites for these PGs. Under the assay conditions used for this study, the binding characteristics suggest a one-site model for each receptor. However, while the capacity of $\mathrm{PGF}_{2 \alpha}$ receptors increased markedly over time with the ageing of CL, by contrast the number of binding sites of the $\mathrm{PGE}_{2}$ receptors decreased progressively from early- to late-luteal phase.

Several studies have identified receptors for both $\mathrm{PGE}_{2}$ and $\mathrm{PGF}_{2 \alpha}$ and their distribution in luteal cells of different species including laboratory rodents and farm animals. Wright et al. (1980) found that affinity and capacity of $\mathrm{PGF}_{2 \alpha}$ receptors in CL of rats do not change across pseudopregnancy. High-affinity $\mathrm{PGF}_{2 \alpha}$ binding sites have been found in bovine CL already in the early luteal phase
(Sakamoto et al. 1995, Wiltbank et al. 1995) when CL are usually resistant to single treatment with exogenous $\mathrm{PGF}_{2 \alpha}$. Moreover, Sakamoto et al. $(1994,1995)$ showed that the expression of mRNA for luteal membrane $\mathrm{PGF}_{2 \alpha}$ receptors and the number and affinity of their binding sites increased only slightly during the oestrous cycle of the bovine. These findings differ from those previously reported by Rao (1974), who demonstrated a marked increase in the affinity of the $\mathrm{PGF}_{2 \alpha}$ receptor of bovine $\mathrm{CL}$, which parallels the increase in sensitivity to $\mathrm{PGF}_{2 \alpha^{-}}$ induced luteolysis during the bovine oestrous cycle. In pigs, $\mathrm{PGE}_{2}$ receptor concentration appeared to be related to CL functional status during the oestrous cycle (Feng \& Almond 1996). Therefore, considerable differences among species exist in the ways receptors for PGs change during the time-course of the CL life span, a feature that adds complexity to the underlying regulatory mechanisms which probably involve also intraluteal factors (Skarzynski \& Okuda 1999). 


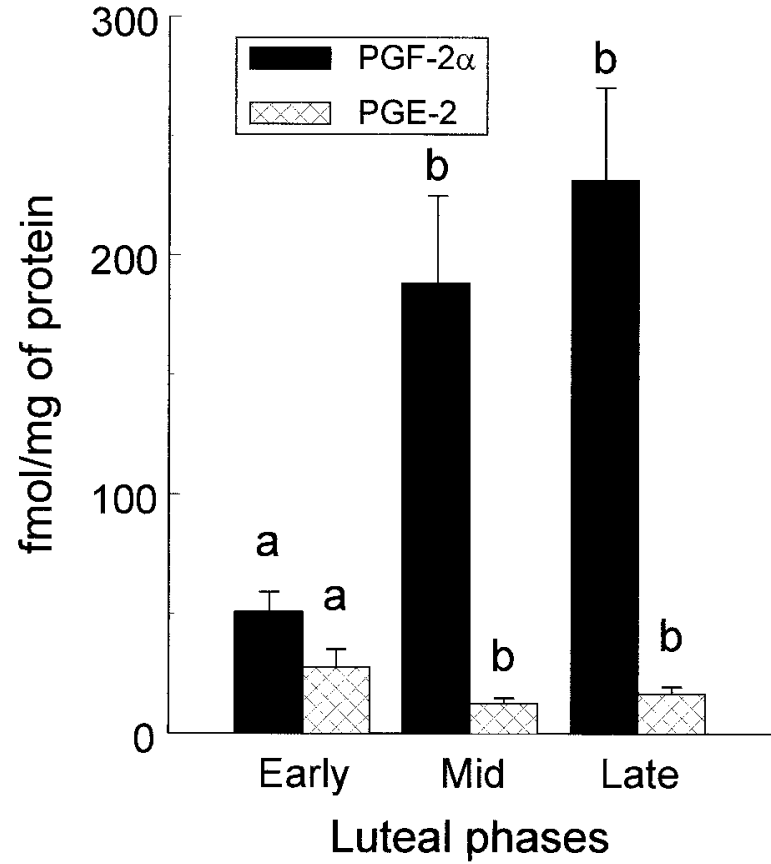

Figure 7 Concentrations (means \pm S.E.M.) of $\mathrm{PGF}_{2 \alpha}$ and $\mathrm{PGE}_{2}$ receptors in $\mathrm{CL}$ of rabbits collected at the early-, mid- and late-luteal phase on days 4, 9 and 13 of pseudopregnancy. Within each series, different letters above the bars indicate significantly different values ( $P \leq 0 \cdot 01$ Dunnett's post test).

Several reports suggest a role of $G$ proteins in the signalling pathways involved in the transduction of prostaglandin actions. The effects of $\mathrm{PGF}_{2 \alpha}$-receptor activation appear to be transduced by the Gp family and those of $\mathrm{PGE}_{2}$ by interaction with a stimulatory $\mathrm{Gp}$ (Olofsson \& Leung 1996). This role has been indirectly confirmed here by the lack of specific prostaglandin-induced responses following the co-application of $\mathrm{Gp}$ inhibitors and either $\mathrm{PGE}_{2}$ or $\mathrm{PGF}_{2 \alpha}$ to $\mathrm{CL}$ in vitro and by the mimicking effects obtained by the addition of $\mathrm{Gp}$ activators. The Gpdependent AC/PKA pathway, regulating NOS enzymatic activity and steroidogenesis, was triggered only on day 4 CL. In older CL, the Gp-activated PLC/PKC pathway prevailed. In CL of both days 9 and 13, activation of the $\mathrm{G}$ protein system evoked a marked luteolytic effect similar to that observed following treatment with $\mathrm{PGF}_{2 \alpha}$. This prostaglandin has been shown to mediate functional luteolysis and luteal regression in the mammalian ovary, with the relevant exception of man and other primates (Niswender et al. 2000). In ovaries from both human and other primate species, however, $\mathrm{PGF}_{2 \alpha}$ does indeed activate the phospholipase $\mathrm{C}$ signalling pathway (Davis et al. 1989). The luteolytic action of $\mathrm{PGF}_{2 \alpha}$ in rabbit CL depends upon the availability of functional receptors on target luteal cells and, following receptor binding, appears to be mediated by several mechanisms integrating a number of second messengers such as PLC and PKC phosphorylation in signal transduction. Prostaglandin $\mathrm{F}_{2 \alpha^{-}}$ receptor occupations in both day 9 and day 13 CL cultured in vitro rapidly stimulated total NOS activity and inhibited progesterone, thus confirming our previous results (Gobbetti et al. 1999, Boiti et al. 2000). In our model, independently of the luteal stages, whenever total NOSlike activity was significantly up-regulated, a functional luteolytic response was observed as evidenced by a marked reduction of progesterone production. The signalling pathway leading to luteolysis was interrupted by incubation with L-NAME. These findings strongly support the hypothesis for a functional role of $\mathrm{NO}$ in the $\mathrm{PGF}_{2 \alpha}$-mediated luteolytic process in rabbit CL. A key role in the regulation of NOS activity should be attributed to $\mathrm{Ca}^{2+}$ mobilization, which increases its free intracellular levels following $\mathrm{PGF}_{2 \alpha}$-receptor occupation. In fact, it is well established that constitutive endothelial NOS requires $\mathrm{Ca}^{2+}$ for the reversible binding of calmodulin to the enzyme to become active and generate NO (Bredt \& Snyder 1990). PGF $2 \alpha$ rapidly induces an increase in phosphoinositide turnover by PLC and, consequently, a rise in intracellular diacylglycerol (DAG) and inositol triphosphate $\left(\mathrm{InP}_{3}\right)$ levels; DAG activates PKC while $\mathrm{InP}_{3}$ frees intracellular $\mathrm{Ca}^{2+}$ (Wiltbank et al. 1991). Conversely, the activation of the receptor for $\mathrm{PGE}_{2}, \mathrm{EP}_{2}$ is associated with elevation of intracellular levels of cAMP (Olofsson \& Leung 1986).

Studies of prostaglandin actions in vitro have often yielded contradictory results on the production of progesterone. In contrast to our present findings, McLean et al. (1987) reported that neither $\mathrm{PGF}_{2 \alpha}$ nor $\mathrm{PGE}_{2}$ altered progesterone secretion by dispersed luteal cells obtained from rabbits at day 10 of pseudopregnancy. Dharmarajan et al. (1989) found that $\mathrm{PGF}_{2 \alpha}$ did not affect progesterone production in the in vitro perfused rabbit ovary in vitro at day 11 of pseudopregnancy. These discrepancies are mainly related to the difference in the in vitro technique used. It remains to be established, however, if the increased progesterone release is due to an actual synthesis rather than to a leakage from dying cells as suggested by Dharmarajan et al. $(1994,1999)$ who reported that rabbit CL undergo spontaneous apoptosis within a few hours when cultured in serum-free medium.

The luteolytic action of $\mathrm{PGF}_{2 \alpha}$ was clearly dependent on the age of the CL. Four-day-old CL remained unaffected by the same luteolytic dose of $\mathrm{PGF}_{2 \alpha}$ which caused a striking reduction in progesterone production by mature CL. On the basis of the binding studies here reported, the age-dependent unresponsiveness of young CL may be the combined results of fewer functional receptors available for $\mathrm{PGF}_{2 \alpha}$ associated with an increase in the number of receptors for $\mathrm{PGE}_{2}$ conveying luteotrophic or antiluteolytic signals. In fact, it has been shown that $\mathrm{PGF}_{2 \alpha}$ can bind to receptors for $\mathrm{PGE}_{2}$ (Christenson et al. 1994, Coleman 1996). Although the low receptor density for $\mathrm{PGF}_{2 \alpha}$ may well explain the resistance to this prostaglandin in the early luteal stage, an impairment of Gp 
coupled to $\mathrm{PGF}_{2 \alpha}$ receptor could not be ruled out. In fact, the addition into the culture medium of activators for either PLC and PKC enzymes caused a marked luteolytic effect not only on day 9 and day $13 \mathrm{CL}$, similar to that obtained by $\mathrm{PGF}_{2 \alpha}$ treatment, but also in day $4 \mathrm{CL}$, when the same prostaglandin was completely ineffective. The increasing $\mathrm{PGF}_{2 \alpha}$ receptor density occurring in the midand late-luteal stages of pseudopregnancy is consistent with the luteolytic effects observed in vitro, which involve interaction of the CL and $\mathrm{PGF}_{2 \alpha}$ itself. Rabbits, however, are completely refractory to $\mathrm{PGF}_{2 \alpha}$ injection until day 12 of pseudopregnancy (Marcinkiewicz et al. 1992), even if they exhibit earlier responsiveness to the $\mathrm{PGF}_{2 \alpha}$ analogue, alfaprostol (Boiti et al. 1998). The lack of response to $\mathrm{PGF}_{2 \alpha}$ in vivo before day 12 of pseudopregnancy is therefore unlikely to be caused by a reduced expression of binding sites for $\mathrm{PGF}_{2 \alpha}$, and suggests the involvement of other factors.

In several species, $\mathrm{PGE}_{2}$ has been identified as a luteotrophic factor and it is supposed to counteract $\mathrm{PGF}_{2 \alpha^{-}}$ induced luteolysis (Henderson et al. 1977, Silvia et al. 1984). PGE $_{2}$ has been involved in the maintenance of the $\mathrm{CL}$ during early pregnancy when progesterone secretion from the CL is essential for the establishment and maintenance of pregnancy (Christenson et al. 1994). According to Grimes et al. (1993), $\mathrm{PGE}_{2}$ enhances progesterone synthesis via cAMP stimulation, as well as the expression of the genes for both steroidogenic enzymes $3 \beta$ hydroxysteroid dehydrogenase ( $3 \beta-\mathrm{HSD})$ and mitochondrial cytochrome $\mathrm{P} 450_{\mathrm{scc}}$ (Li et al. 1993). Our in vitro study demonstrated direct $\mathrm{PGE}_{2}$-receptor-mediated effects in $\mathrm{CL}$ of pseudopregnant rabbits only in the early luteal phase. In fact, $\mathrm{PGE}_{2}$-stimulated progesterone production was abolished by co-incubation with Gp inhibitor, while similar results were obtained when Gp activator was used. On day $4 \mathrm{CL}$, the action on luteal cell steroidogenesis following binding is exerted at multiple sites and probably involves $\mathrm{AC}$ and PKA up-regulation. In fact, cAMPderivative and PKA-activator likewise stimulated progesterone releases by CL of the same age. That the effect is at least partially exerted through cAMP-mediated mechanisms is further supported by the findings that $\mathrm{PGE}_{2}$-induced progesterone release was abolished by cotreatments with inhibitors of the AC/PKA systems. As previously stated, the stimulatory action of $\mathrm{PGE}_{2}$ was found to be present only on day $4 \mathrm{CL}$, while, thereafter in mature CL, a positive response was not observed. Interestingly, a similar differential responsiveness to $\mathrm{PGE}_{2}$ has also been reported in monkey; incubation with this prostaglandin increased progesterone production by luteal cells obtained from CL in the early phase of the menstrual cycle on days 3-5, but was ineffective in subsequent stages (Brannian \& Stouffer 1991). However, the absence of any $\mathrm{PGE}_{2}$-induced luteotrophic effects in rabbit CL at days 9 and 13 seems not to be associated with a complete lack of luteal membrane $\mathrm{PGE}_{2}$ receptors. The unresponsiveness of both day 9 and day $13 \mathrm{CL}$ to $\mathrm{PGE}_{2}$ could also be ascribed to prior in vivo desensitization to $\mathrm{PGE}_{2}$ receptor or to receptor uncoupling from AC. Taken together, these results suggest that $\mathrm{PGE}_{2}$ may not have a relevant role in $\mathrm{CL}$ of either mid- or late-luteal stages of pseudopregnancy. However, even if $\mathrm{PGE}_{2}$ enhances progesterone production only in the early luteal phase, AC/cAMP and PKA second messenger systems, working in a luteotrophic or luteoprotective fashion, are present in CL of both mid- and late-luteal phases. Notably, maximal stimulation of progesterone production occurred on day $9 \mathrm{CL}$ in the presence of AC and PKA activators. Even if $17 \beta$-oestradiol has been identified as the principal luteotrophic hormone, rabbit CL exhibit $\mathrm{LH}$ receptors, $\mathrm{LH}$-responsive $\mathrm{AC}$ and a cAMP-dependent protein kinase enzyme system which is specifically activated in a time- and a dose-dependent manner (Hunzicker-Dunn \& Birnbaumer 1976, Hoyer et al. 1986).

In the present study we demonstrated that the receptor capacity of both $\mathrm{PGF}_{2 \alpha}$ and $\mathrm{PGE}_{2}$ changes in $\mathrm{CL}$ of pseudopregnant rabbits during the luteal phases. However, the factors that may influence the increased expression of $\mathrm{PGF}_{2 \alpha}$ receptor during pseudopregnancy while reducing that of $\mathrm{PGE}_{2}$, remain to be explored. Differential binding capacities of $\mathrm{PGF}_{2 \alpha}$ and $\mathrm{PGE}_{2}$ receptors between earlyand both mid-and late-luteal stages may reflect functional differences not yet understood and in this respect it would be interesting to compare their characteristics in relation to physiological conditions of pregnancy and pseudopregnancy. The mechanisms by which the CL of rabbit are refractory to the luteolytic action of $\mathrm{PGF}_{2 \alpha}$ during the early period of pseudopregnancy remain to be disclosed and better characterized, but are probably mediated by factors other than a complete lack of luteal receptor-ligand interactions. The combined results of this study provide further evidence that the contrasting prostaglandininduced luteolytic and luteotrophic effects observed in rabbit CL cultured in vitro are mediated by different receptors for $\mathrm{PGF}_{2 \alpha}$ and $\mathrm{PGE}_{2}$ coupled to $\mathrm{Gp}$ families. Moreover, this study confirms that PLC/PKC and AC/ PKA systems play an important role in the transduction of signals regulating prostaglandin-induced luteolytic and luteotrophic effects respectively.

\section{Acknowledgements}

This work was supported by a grant from Ministero dell'Università e della Ricerca Scientifica e Tecnologica. The authors gratefully acknowledge the revision of the English text by Dr James Burge of the Linguistic Institute of Camerino University.

\section{References}

Alila HW, Corradino RA \& Hansel W 1987 A comparison of the effects of cyclooxygenase prostanoids on progesterone production by small and large bovine luteal cells. Prostaglandins 33 227-239. 
Balapure AK, Caicedo IC, Kawada K, Watt DS, Rexroad CE Jr \& Fitz TA 1989 Multiple classes of prostaglandin $\mathrm{F}_{2 \alpha}$ binding sites in subpopulations of ovine luteal cells. Biology of Reproduction 41 385-392.

Boiti C, Canali C, Zerani M \& Gobbetti A 1998 Changes in refractoriness of rabbit corpora lutea to a prostaglandin F-2 $\alpha$ analogue, alfaprostol, during pseudopregnancy. Prostaglandins 56 255-264.

Boiti C, Zerani M, Zampini D \& Gobbetti A 2000 Nitric oxide synthase activity and progesterone release by isolated corpora lutea of rabbits in early- and mid-luteal phase of pseudopregnancy are differently modulated by prostaglandin E2 and prostaglandin F2 $\alpha$ via adenylate cyclase and phospholipase C. Journal of Endocrinology 164 179-186.

Brannian JD \& Stouffer RL 1991 Progesterone production by monkey luteal cell subpopulations at different stages of the menstrual cycle changes in agonist responsiveness. Biology of Reproduction 44 141-149.

Bredt DS \& Snyder SH 1990 Isolation of nitric synthetase, a calmodulin requiring enzyme. PNAS 87 682-685.

Carlson JC \& Gole JWD 1978 CL regression in the pseudopregnant rabbit and the effects of treatment with prostaglandin F-2 $\alpha$ and arachidonic acid. Journal of Reproduction and Fertility 53 381-387.

Chegini N, Lei ZM, Rao CV \& Hansel W 1991 Cellular distribution and cycle phase dependency of gonadotropin and eicosanoid binding sites in bovine corpora lutea. Biology of Reproduction $\mathbf{4 5}$ 506-513.

Christenson LK, Farley DB, Anderson LH \& Ford SP 1994 Luteal maintenance during early pregnancy in the pig: role for prostaglandin $\mathrm{E}_{2}$. Prostaglandins 47 61-75.

Coleman RA 1996 Prostanoid receptors: classification, characterisation and therapeutic relevance. In Eicosanoids: From Biotechnology to Therapeutic Applications, pp 137-154. Eds GC Folco, B Samuelsson, J Maclouf \& GP Velo. New York: Plenum.

Davis JS, Tedesco TA, Maroulis GB \& Waakland LL 1989 Effects of human chorionic gonadotropin, prostaglandin F2 alpha and protein kinase $\mathrm{C}$ activators on the cyclic AMP and inositol phosphate second messenger system in cultured human granulosa luteal cells. Molecular and Cellular Endocrinology 65 187-193.

Dharmarajan AM, Sueoka K, Miyazaki T, Atlas SJ, Ghodgaonkar RB, Dubin NH, Zirkinand BR \& Wallach EE 1989 Prostaglandin and progesterone secretion in the in vitro perfused pseudopregnant rabbit ovary. Endocrinology 124 1198-1203.

Dharmarajan AM, Goodman SB, Tilly KI \& Tilly JL 1994 Apoptosis during functional corpus luteum regression: evidence of role for chronic gonadotropin in promoting luteal cell survival. Endocrine Journal 2 295-303.

Dharmarajan AM, Hisheh S, Singh B, Parkinson S, Tilly KI \& Tilly JL 1999 Antioxidants mimic the ability of chorionic gonadotropin to suppress apoptosis in the rabbit corpus luteum in vitro: a novel role for superoxide dismutase in regulating bax expression. Endocrinology 140 2555-2561.

Duncan DB 1955 Multiple range and multiple F test. Biometrics 11 $1-42$.

Feng SM \& Almond GW 1996 Identification and distribution of prostaglandin E receptors on porcine luteal cells. Biology of Reproduction 54 1366-1374.

Ford SP \& Christenson LK 1991 Direct effects of oestradiol-17 $\beta$ and prostaglandin $E_{2}$ in protecting pig corpora lutea from a luteolytic dose of prostaglandin $\mathrm{F}_{2 \alpha}$. Journal of Reproduction and Fertility $\mathbf{9 3}$ 203-209.

Gobbetti A, Zerani M \& Bellini-Cardellini L 1992 Relationships among mammalian gonadotropin-releasing hormone, prostaglandins and sex steroids in the brain of crested newt, Triturus carnifex. Prostaglandins 44 209-218.

Gobbetti A, Boiti C, Canali C \& Zerani M 1999 Nitric oxide synthase acutely regulates progesterone production by in vitro cultured rabbit corpora lutea. Journal of Endocrinology 160 275-283.
Grimes RW, Samaras SE \& Hammond JM 1993 Divergent actions of prostaglandins-E2 and F2 alpha on the regulation of insulin-like growth factor-binding protein-3 in luteinized granulosa cells. Endocrinology 132 141-146.

Henderson KM, Scaramuzzi RJ \& Baird DT 1977 Simultaneous infusion of prostaglandin $\mathrm{E}_{2}$ antagonizes the luteolytic action of prostaglandin $\mathrm{F}_{2 \alpha}$ in vivo. Journal of Endocrinology 72 379-383.

Hoyer PB, Keyes PL \& Niswender GD 1986 Size distribution and hormonal responsiveness of dispersed rabbit luteal cells during pseudopregnancy. Biology of Reproduction 34 905-910.

Hunzicker-Dunn M \& Birnbaumer L 1976 Adenylyl cyclase activities in ovarian tissues. II. Regulation of responsiveness to LH, FSH and $\mathrm{PGE}_{2}$ in the rabbit. Endocrinology 99 185-197.

Kehl SJ \& Carlson JC 1981 Assessment of the luteolytic potency of various prostaglandin in the pseudopregnant rabbit. Journal of Reproduction and Fertility 62 117-122.

Li XM, Juorio AV \& Marvin BD 1993 Prostaglandins alter the abundance of messenger ribonucleic acid for steroidogenic enzymes in cultured porcine granulosa cells. Biology of Reproduction 48 1360-1366.

McLean MP, Derick RJ \& Miller JB 1987 The effect of human chorionic gonadotropin, dybutyryl cyclic adenosine $3^{\prime}, 5^{\prime}$ monophosphate, prostaglandins, and 25-hydroxycholesterol on acute progesterone secretion by dissociated rabbit luteal cells in vitro: evidence for independent effect of human chorionic gonadotropin and lipoproteins. Biology of Reproduction 36 854-863.

Marcinkiewicz JL, Moy ES \& Bahr JM 1992 Change in responsiveness of rabbit corpus luteum to prostaglandin F2 $\alpha$ during pregnancy and pseudopregnancy. Journal of Reproduction and Fertility $94305-310$.

Niswender GD, Schwall RH, Fitz TA, Farin CE \& Sawyer HR 1985 Regulation of luteal function in domestic ruminants: new concepts. Recent Progress in Hormone Research 41 101-151.

Niswender GD, Juengek JL, Silva PJ, Rollyson MK \& McIntush EW 2000 Mechanisms controlling the function and life span of the corpus luteum. Physiological Review 80 1-29.

O'Grady JP, Caldwell BV, Auletta FJ \& Speroff L 1972 The effects of an inhibitor of prostaglandin synthesis (indomethacin) on ovulation, pregnancy and pseudopregnancy in the rabbit. Prostaglandins $\mathbf{1}$ 97-106.

Olofsson JI \& Leung PCK 1996 Prostaglandins and their receptors: implications for ovarian physiology. Biological Signals $\mathbf{5}$ 90-100.

Rao CV 1974 Concentration of prostaglandin receptors in the bovine corpus luteum cell membranes. Journal of Biological Chemistry 249 7203-7209.

Rao CV, Carman FR, Chegini N \& Schultz GS 1984 Binding sites for epidermal growth factor in human fetal membranes. Journal of Clinical Endocrinology and Metabolism 58 1034-1042.

Sakamoto K, Ezashi T, Miwa K, Okuda-Ashitaka E, Houtani T, Sugimoto T, Ito S \& Hayaishi O 1994 Molecular cloning and expression of a cDNA of the bovine $\mathrm{PGF}_{2 \alpha}$ receptor. Journal of Biological Chemistry 269 3881-3886.

Sakamoto K, Miwa K, Ezashi T, Okuda-Ashitaka E, Okuda K, Houtani T, Sugimoto T, Ito S \& Hayaishi O 1995 Expression of mRNA encoding the prostaglandin $\mathrm{F}_{2 \alpha}$ receptor in bovine corpora lutea throughout the estrous cycle and pregnancy. Journal of Reproduction and Fertility 103 99-105.

Silvia WJ, Fitz TA, Mayan MH \& Niswender GW 1984 Cellular and molecular mechanisms involved in luteolysis and maternal recognition of pregnancy in the ewe. Animal Reproduction Science 7 $57-74$.

Skarzynski DJ \& Okuda K 1999 Sensitivity of bovine corpora lutea to prostaglandin $\mathrm{F}_{2 \alpha}$ is dependent on progesterone, oxytocin and prostaglandins. Biology of Reproduction 60 1292-1298. 
Sokal RR \& Rohlf FJ 1981 Biometry, pp 253-261. New York: WH Freeman and Co.

Wiepz GJ, Wiltbank MC, Nett TM, Niswender GD \& Sawyer HR 1992 Receptors for prostaglandins $\mathrm{F}_{2 \alpha}$ and $\mathrm{E}_{2}$ in ovine corpora lutea during maternal recognition of pregnancy. Biology of Reproduction 47 984-991.

Wiltbank MC, Diskin MG \& Niswender GD 1991 Differential actions of second messenger systems in the corpus luteum. Journal of Reproduction and Fertility 43 (Suppl) 65-75.

Wiltbank MC, Shio TF, Bergfelt DR \& Ginther OJ 1995

Prostaglandin $\mathrm{F}_{2 \alpha}$ receptor in the early bovine corpus luteum. Biology of Reproduction $\mathbf{5 2}$ 74-78.
Wright K, Pang CY \& Behrman HR 1980 Luteal membrane binding of prostaglandin F2 $\alpha$ and sensitivity of corpora lutea toprostaglandin F2 $\alpha$-induced luteolysis in pseudopregnant rats. Endocrinology 106 1333-1337.

Zelinsky-Wooten MB \& Stouffer RL 1990 Intraluteal infusions of prostaglandins $\mathrm{E}, \mathrm{D}, \mathrm{I}$ and $\mathrm{A}$ series prevent $\mathrm{PGF}_{2 \alpha}$-induced, but not spontaneous, luteal regression in Rhesus monkeys. Biology of Reproduction 43 507-516.

Received 21 July 2000

Revised manuscript received 18 September 2000 Accepted 9 October 2000 